\title{
IMPLIKASI KEBIJAKAN PENDIDIKAN ERA SOEHARTO PADA EKSISTENSI MADRASAH
}

\section{Toto Suharto}

Institut Agama Islam Negeri (IAIN) Surakarta

Jl. Pendawa RT 002/01 Pucangan Kartosuro Solo Jawa Tengah

Email: totosuharto2000@yahoo.com

\begin{abstract}
ABSTRAK
Tulisan ini berupaya melacak sejumlah trauma politis era Soeharto (Orde Baru) yang menimpa pendidikan Islam khususnya madrasah. Pembahasan dilakukan secara historis dan analitis terhadap sejumlah kebijakan dan fakta sejarah penyelenggaraan madrasah pada masa Soeharto. Fakta dan data ditelaah melalui bidang politik pendidikan Islam. Hasil kajian menunjukkan bahwa secara umum kebijakan politik pendidikan pada masa Soeharto bersifat; 1) sentralistis, 2) diskriminatif dan 3) cenderung kuantitatif. Ia bertukar balik menjadi politisasi pendidikan dalam rangka melanggengkan kekuasaan. Salah satu lembaga pendidikan Islam yang menjadi 'korban politik' Soeharto adalah madrasah. Kebijakan serba ijazah, persamaan dan akreditasi baik melalui Departemen Agama maupun Pendidikan dan Kebudayaan telah berhasil mengontrol (kualitas) perkembangan madrasah. Walaupun secara kuantitas pertumbuhan madrasah sangat pesat namun secara kualitas sangat rendah sehingga ia termarjinalkan. Madrasah masih identik dengan 'sekolah kelas dua'. Substansi madrasah sebagai sebuah pemberdayaan masyarakat pun sedemikian rupa sukses 'dibonsai' oleh rezim Soeharto. Kini, masih sulit menemukan madrasah swasta yang berkualitas sama/di atas rata-rata sekolah negeri.
\end{abstract}

Kata Kunci: Madrasah, Departemen Agama, Orde Baru

\begin{abstract}
This paper seeks to track a number of political trauma in Soeharto era (New Order) that befall of Islamic education, particularly in madrasah. The discussion is carried out historically and analytically to a number of policies and the implementation of Islamic bistorical facts under Subarto. Facts and data are reviewed through politics of Islamic education. The study results showed that in general education policies under Subarto are: 1) centralized, 2) discriminatory and 3) tends to be quantitative. They swapped back into the politicization of education in order to preserve power. One of the Islamic educational institutions that became the political victim of Soeharto was madrasah. Ijazaisme policy, equality and accreditation either through the Ministry of Religious Affairs and Education and Culture have managed to control the (quality of) the development of madrasah. Although the quantity of madrasah grew very rapidly but the quality is so low that made madrasah marginalized. Until now the madrasah is still considered 'the secondclass schools'. The substance of the madrasah as a community empowerment was restricted by the Soeharto regime. As a result, it is still difficult to find qualified private madrasab which is equal/ above average quality of the public school.
\end{abstract}

Keywords: Madrasah, Department of Religion, New Order 


\section{PENDAHULUAN}

Berdirinya pemerintahan Orde Baru ditandai sejak Soeharto ditunjuk sebagai Presiden Sementara, pada tanggal 12 Pebruari 1967, melalui Dekrit MPRS (Majelis Permusyawaratan Rakyat Sementara) (Faisal Ismail, 1999: 104107). Sebagai suatu rezim yang pernah berkuasa di Indonesia, pemerintahan Orde Baru memiliki empat pola dasar pengelolaan tatanan kenegaraan dan kebangsaan yaitu; Pertama, Pancasila dan UUD 1945 yang harus dilaksanakan secara murni dan konsekuen. Kedua, bercita-cita mengisi kemerdekaan dengan berupaya menciptakan keadilan dan kemakmuran bagi seluruh rakyat Indonesia berdasarkan nilai-nilai luhur Pancasila dan UUD 1945. Ketiga, bercita-cita menciptakan sistem negara yang menempatkan hukum sebagai supremasi kehidupan bernegara dan membangun masyarakat yang demokratis. Keempat, melaksanakan pembangunan di segala bidang kehidupan (Team Pembinaan Penatar dan Bahan Penataran Pegawai Republik Indonesia, 1978: 167).

Pemerintah Orde Baru, dengan empat pola dasar di atas, dalam pengamatan Azra (1999: 62), telah menjadikan pembangunan ekonomi sebagai kunci dan kebijakan pokoknya. Dengan berorientasi pada pembangunan ekonomi, Indonesia di era Orde Baru sering dipandang sebagai negara yang mengikuti paham bahwa pembangunan (modernisme) adalah segalanya (developmentalism). Saat itu, pembangunan seolah-olah telah dipandang sebagai 'agama baru' bagi umumnya negara-negara dunia ketiga, termasuk Indonesia. Ia dipahami sebagai sebuah proses yang setahap demi tahap berupaya menuju modernitas. Konsekuensi logis dari 'pembangunanisme' ini timbul eksploitasi ekonomi, hegemoni kultural, dominasi kekuasaan dan gender serta kerusakan/pencemaran lingkungan. Sejumlah permasalahan tersebut melahirkan semacam 'budaya tanding' yang diwakili terutama oleh lembaga swadaya masyarakat (LSM) yang lebih transformatif dan sifatnya mengimbangi kekuasaan pemerintah (Fakih, 1996: 69-107).

Selain menimbulkan sejumlah persoalan ekonomi, pembangunanisme (developmentalism) juga menimbulkan sejumlah persoalan politis. Untuk dapat mencapai tingkat pertumbuhan ekonomi yang stabil, pemerintah sangat menekankan prinsip penciptaan stabilitas keamanan dan politik. Dalam pandangan pemerintah, apabila bidang keamanan dan politik selalu dalam keadaan stabil, maka pembangunan ekonomi dapat dijalankan dengan lancar. Pembangunanisme pada masa Orde Baru itu juga menimbulkan masalah dalam bidang pendidikan. Setidaknya, ada tiga persoalan utama pendidikan Indonesia pada masa 'orba' (Orde Baru) yang dampaknya hingga saat ini masih terasa.

Pertama, kebijakan pendidikan nasional menjadi sangat sentralistik dan menekankan uniformitas (keseragaman). Hal ini menyebabkan format kurikulum, buku ajar, bahkan hingga penilaian hasil pendidikan diatur secara serba seragam dengan mengikuti selalu harus petunjuk atau indoktrinasi dari pemerintah pusat Jakarta. Kebijakan seperti ini pada gilirannya menutup ruang gerak kreativitas, pengembangan dan improvisasi pendidikan yang sesuai dengan 
kondisi sosial, budaya dan ekonomi masyarakat setempat (Azra, 2002: xvi; Tilaar, 1998: 26; dan Suparno dkk., 2003: 19).

Kedua, kebijakan pendidikan nasional menjadi diskriminatif dalam memperlakukan sekolah swasta, sehingga memunculkan kesan bahwa pendidikan hanya milik pemerintah, bukan milik masyarakat. Kondisi ini menyebabkan adanya jurang pemisah antara "negeri" dan "swasta". Mayoritas dana, sarana dan perhatian pemerintah dipusatkan pada sekolah negeri, sehingga kualitas sekolah swasta terabaikan (Mastuhu, 2004: 32-33 dan Darmaningtyas, 2004: 38-41). Kebijakan diskriminatif ini juga diberlakukan antara sekolah umum milik Departemen Pendidikan dan Kebudayaan dengan sekolah agama (madrasah) milik Departemen Agama. Menurut catatan Azra (2002: 8-9), kebijakan yang tidak adil dalam penganggaran dan pendanaan pemerintah terhadap subsidi per kapita bagi lembaga pendidikan Islam tampak dalam indeks biaya per kapita pendidikan per siswa di madrasah yang jauh lebih kecil dibanding di sekolah umum. Kebijakan diskriminatif ini berimplikasi pada terbatasnya kesempatan memperoleh pendidikan (limited capacity) bagi seluruh warga. Abbas (2003: 65-70) menilai, kebijakan diskriminatif ini menunjukkan bahwa dimensi HAM (hak asasi manusia) dalam pendidikan pada masa Orde Baru belum ditegakkan dengan baik.

Ketiga, sistem pendidikan pada masa 'orba' belum mampu memberdayakan masyarakat secara kualitas, meskipun secara kuantitas pendidikan pada masa itu telah memperlihatkan prestasi yang baik. Secara kuantitas, peserta didik dari tahun ke tahun terus meningkat, tetapi secara kualitas, tidak dapat dibanggakan. Laporan UNDP (United Nations Development Programme) tahun 1996 menunjukkan bahwa Indeks Kualitas SDM (Human Development Index/HDI) Indonesia berada pada urutan ke 102 dari 174 negara di dunia. Kurangnya pemberdayaan kualitas pendidikan bagi peningkatan kualitas masyarakat ini disebabkan karena pemerintah 'orba' sudah sejak awal telah menskenariokan (secara politis) pendidikan sebagai salah satu instrumen untuk melanggengkan kekuasaannya. Kurikulum harus bersifat nasional. Evaluasi belajar terpusat melalui Nilai Ebtanas Murni (NEM). Pembelajaran terlalu mementingkan aspek kognitif dengan mengabaikan aspek afektif dan psikomotor. Praksis pendidikan menjadi subject matter oriented bukan children oriented (Suyanto dan Hisyam, 2000: 4-7).

Dunia pendidikan bagi Orde Baru merupakan dunia birokrasi. Artinya pendidikan nasional harus dikelola secara sentralistik, tidak ada otonomisasi penyelenggaraan pendidikan dan berbagai bentuk inovasi pendidikan hanya dilakukan di level atas. Sistematisasi dan sentralisasi pendidikan melalui birokrasi ini berimbas pada pelaksanaan pendidikan Islam di Indonesia, terutama pada lembaga madrasah dan pesantren, yang disinyalir sebagai lembaga pendidikan milik masyarakat, yang pada umumnya dikelola oleh swasta sebagai milik organisasi, yayasan atau perorangan. Hingga akhir Orde Baru jumlah madrasah (ibtidaiyah, tsanawiyah dan aliyah) di Indonesia mencapai 36.000-an dan 90 persen dari jumlah tersebut berstatus swasta (Fadjar, 1998 : 119 dan 123). 
Tulisan ini bermaksud melacak jejak dan dampak kebijakan penyelenggaraan pendidikan pada masa Orde Baru terhadap pendidikan Islam terutama madrasah. Pembahasan dilakukan secara historis dan analitis terutama berkenaan dengan sejumlah kebijakan penyelenggaraan pendidikan pada masa Orde Baru yang secara umum bersifat sentralistis, diskriminatif dan kuantitatif. Sejumlah kebijakan dan fakta historis tersebut ditelaah melalui disiplin politik pendidikan Islam. Rezim Soeharto (Orde Baru), melalui Departemen Agama Republik Indonesia saat itu merupakan instrumen politis yang ampuh untuk mengontrol dan mengawasi, di satu sisi lembaga pendidikan negeri dan di sisi lain mendiskriminasi lembaga pendidikan swasta, termasuk madrasah.

\section{PEMBAHASAN}

Suparno dkk. (2003: 19) mengatakan bahwa sentralisasi pendidikan adalah proses pendidikan di mana semua hal yang mencakup pelaksanaan aspek pendidikan diatur dari pusat. Kurikulum, guru, seragam sekolah, waktu belajar, pelaksanaan tujuan, semuanya diatur dan ditentukan oleh pusat. Keuntungan dari adanya sentralisasi pendidikan adalah standar mutu pendidikan menjadi cukup jelas, yaitu beberapa sekolah yang bermutu dapat dijadikan standar dan acuan oleh pemerintah pusat untuk memajukan sekolah yang kurang bermutu/berkualitas. Namun demikian sentralisme pendidikan juga menimbulkan kerugian yang boleh jadi lebih banyak dan dampaknya sangat laten. Misalnya, sekolah tidak memperoleh kebebasan untuk menentukan dan mengembangkan sendiri arah dan tujuan didirikannya sekolah tersebut yang biasanya disesuaikan dengan kebutuhan dan tuntutan idealnya masing-masing. Sekolah yang kemajuannya pesat akan terhambat karena dipaksa mengikuti aturan main dari pusat. Kreativitas sekolah lokal pun mati. Pihak sekolah banyak yang memanipulasi laporan agar selalu kelihatan baik dan yang penting memenuhi tuntutan pusat yang lebih banyak bersifat formal dan birokratis. Pemerintah pun tidak memperhatikan kekhasan sekolah. Dalam konteks kebudayaan, sentralisme pendidikan merupakan proses pembudayaan yang bersifat linier. Penyelenggaraan pendidikan kebudayaan dilakukan secara satu arah, dari pusat menuju daerah. Dengan sendirinya, model ini tidak mengakar pada kebutuhan masyarakat tetapi menyempit pada sejumlah keinginan kekuasaan pusat (Tilaar, 2002: 30-31).

Sentralisasi pendidikan menyuburkan praktik birokrasi pendidikan yang kaku dan mekanis, yaitu cenderung menyamakan pendidikan dengan pabrik. Para lulusan dicetak untuk bermental "juklak" dan "juknis" yang siap melayani kemauan industri yang seragam, yakni profit. Semua ini bermuara pada politik kebijakan Orde Baru tentang pentingnya pembangunan ekonomi sebagai hal yang harus diprioritaskan. Lulusan harus siap bekerja sehingga memenuhi standar pertumbuhan ekonomi dan mekanis karena harus dengan mudah dapat diatur dalam rangka menciptakan stabilitas keamanan nasional. Stabilitas selain menekankan pada aspek keamanan juga bersifat politis. Tidak mungkin ada 
dinamisasi dalam stabilitas. Pertumbuhan berarti mengarahkan kemampuan untuk mengejar target kuantitatif. Untuk dapat mencapai stabilitas dan pertumbuhan, aparat pemerintah yang terwujud dalam sejumlah lembaga birokrasi harus kuat dan mampu mengontrol segala potensi dan kekuatan serta perkembangan yang ada di masyarakat. Konsekuensinya, sentralisasi di segala bidang harus terus dipelihara dan dijalankan agar seluruh kegiatan masyarakat dapat dikontrol termasuk kegiatan dalam bidang pendidikan. Lembaga politik sangat dominan mempengaruhi terhadap lembaga pendidikan. Tidak ada politik pendidikan yang ada hanya pendidikan merupakan alat/kendaraan politik (Zamroni, 2000: 84-85).

Jika pada masa 'orba' telah terjadi politisasi pendidikan di Indonesia maka pada masa itu pun telah terjadi politisasi terhadap pendidikan Islam Indonesia. Politisasi pendidikan Islam Indonesia pascakemerdekaan sangat erat hubunganya dengan peran lembaga Kementerian Agama Republik Indonesia yang resmi didirikan oleh pemerintah pada tanggal 3 Januari tahun 1946 di Yogyakarta. Lahirnya Departemen Agama didasarkan oleh adanya Penetapan Pemerintah RI tahun 1946 No. 1/S.D. dan sesuai dengan usulan dari Perdana Menteri dan Badan Pekerja Komite Nasional Pusat (Koesnodiprodjo, t.t: tanpa halaman).

Usulan pembentukan Kementerian Agama RI pertama kali diajukan kepada BP-KNIP (Badan Pekerja Komite Nasional Indonesia Pusat) pada tanggal 11 Nopember 1946 oleh K.H. Abudardiri, K.H. Saleh Su'aidy dan M. Sukoso Wirjosaputro, yang semuanya merupakan anggota KNIP dari Karesidenan Banyumas. Usulan ini mendapat dukungan dari Mohammad Natsir, Muwardi, Marzuki Mahdi dan Kartosudarmo yang semuanya juga merupakan anggota KNIP untuk kemudian memperoleh persetujuan BP-KNIP. Kelihatannya usulan tersebut kembali dikemukakan dalam sidang pleno BPKNIP tanggal 25-28 Nopember 1945 bertempat di Fakultas Kedokteran UI Salemba. Wakil-wakil KNIP Daerah Karesidenan Banyumas dalam pemandangan umum atas keterangan pemerintah kembali mengusulkan, antara lain: "Supaya dalam negara Indonesia yang sudah merdeka ini jangan hendaknya urusan agama hanya disambillalukan dalam tugas Kementerian Pendidikan, Pengajaran dan Kebudayaan atau departemen-departemen lainnya, tetapi hendaknya diurus oleh suatu Kementerian Agama tersendiri". Usul tersebut mendapat sambutan dan dikuatkan oleh tokoh-tokoh Islam yang hadir dalam sidang KNIP pada waktu itu. Tanpa pemungutan suara, Presiden Soekarno memberikan isyarat kepada Wakil Presiden Mohamad Hatta, yang kemudian menyatakan, bahwa "adanya Kementerian Agama tersendiri mendapat perhatian pemerintah". Sebagai realisasi dan janji tersebut, pada 3 Januari 1946 pemerintah mengeluarkan ketetapan No. 1/S.D. yang antara lain berbunyi: "Presiden Republik Indonesia, Mengingat: Usul Perdana Menteri dan Badan Pekerja Komite Nasional Pusat, memutuskan: Mengadakan Departemen Agama”. Keputusan dan penetapan pemerintah ini dikumandangkan di udara oleh RRI ke 
seluruh dunia dan disiarkan oleh pers dalam dan luar negeri, dengan H. Rasjidi BA sebagai Menteri Agama yang pertama (Azra, 1998: 5).

Pembentukan Kementerian Agama RI segera menimbulkan kontroversi di antara berbagai pihak di dalam masyarakat Indonesia. Kaum Muslim umumnya memandang bahwa keberadaan Kementerian Agama merupakan suatu keharusan sejarah. Ia merupakan kelanjutan dari instansi yang bernama Shumubu (Kantor Urusan Agama) pada masa pendudukan Jepang, yang mengambil preseden dari Het Kantoor voor Inlandsche Zaken (Kantor untuk Urusan Pribumi) pada masa kolonial Belanda. Bahkan sebagian Muslim melacak eksistensi Kementerian Agama ini lebih jauh lagi, ke masa kerajaan-kerajaan Islam atau kesultanan, yang sebagian besar memiliki struktur dan fungsionaris yang menangani urusan-urusan keagamaan. Akan tetapi, beberapa pengamat berargumen bahwa pembentukan Kementerian Agama merupakan bagian dari strategi Sjahrir untuk mendapatkan dukungan bagi kabinetnya dari kaum Muslim. Rosihan Anwar, tokoh sosialis Muslim, misalnya, menyatakan pandangan ini berdasarkan pada pengakuan Sjahrir bahwa kaum Muslim merupakan mayoritas penduduk Indonesia, yang secara alamiah wajar memerlukan kementerian khusus untuk mengelola masalah-masalah keagamaan mereka (Azra, 1998: 6).

Sejumlah pemimpin Indonesia, terutama dari kalangan non-Muslim dan nasionalis, memandang Kementerian Agama merupakan konsesi yang terlalu besar dari republik yang baru berdiri kepada kaum Muslim. Mereka khawatir kementerian ini akan didominasi pejabat-pejabat Muslim dan dengan demikian akan lebih memprioritaskan urusan-urusan Islam daripada urusan agama-agama lain yang ada di Indonesia. Di antara mereka ada yang menuduh bahwa Kementerian Agama merupakan langkah pertama kaum Muslim untuk mewujudkan "negara Islam" di Indonesia, setelah mereka gagal dalam sidang BPUPKI untuk menjadikan Islam sebagai dasar negara. Bentuk tipikal oposisi kalangan non-Muslim terhadap eksistensi Kementerian Agama dapat terlihat dari pandangan Bakker, pemimpin Katolik yang bermukim di Indonesia. Bakker menyatakan bahwa sejak semula Kementerian Agama merupakan "kubu Islam dan batu loncatan pembentukan negara Islam". Tuduhan ini ditanggapi oleh para pemimpin Islam seperti misalnya oleh Wahid Hasyim, pemimpin NU yang kemudian menjabat Menteri Agama periode 1950-1952. Ia menyatakan, adalah pantas bagi Kementerian Agama untuk memberikan perhatian lebih besar kepada masalah-masalah Islam, karena jumlah penduduk Muslim jauh lebih banyak dibandingkan dengan jumlah kaum non-Muslim. Karena itu, tugas-tugas untuk pengelolaan masalah-masalah Islam dan kaum Muslim tidak sama besarnya dengan penanganan masalah-masalah kaum non-Muslim (Azra, 1998: 7-8). Dengan demikian dasar kelahiran kementerian Agama RI merupakan representasi kaum Muslim Indonesia dalam rangka memperjuangkan aspirasi umat Islam di Indonesia, termasuk dalam perkara penyelenggaraan pendidikan Islam. 
Salah satu tugas Kementerian Agama RI adalah "menaruh perhatian dan penghargaan serta memimpin madrasah-madrasah yang di masa penjajahan tidak mendapat penghargaan sama sekali”. Untuk melaksanakan tugas ini, Kementerian Agama membentuk Bagian Pendidikan Agama yang kemudian diganti menjadi Jawatan Pendidikan Agama (Japenda). Berdasarkan Peraturan Menteri Agama No. 10 Tahun 1952 bab II pasal 4, jawatan ini memiliki enam lapangan pekerjaan, yaitu: (1) melaksanakan asas Ketuhanan Yang Maha Esa, menjaga bahwa tiap-tiap penduduk mempunyai kemerdekaan memeluk agama dan beribadah menurut agama dan kepercayaannya masing-masing, serta memelihara perkembangan aliran-aliran agama secara sehat; (2) menyelenggarakan dan mengatur pendidikan agama di sekolah-sekolah negeri dan partikelir; (3) menyelenggarakan, mengatur dan menyokong pendidikan dan pengajaran di madrasah-madrasah dan perguruan-perguruan agama lainnya; (4) menyelenggarakan dan mengatur pendidikan guru dan hakim agama; (5) mengadakan perpustakaan, kitab-kitab, majalah dan lain-lain yang berfaedah untuk pendidikan dan pengajaran agama; dan (6) mempelajari soal-soal dan merencanakan hal-hal yang berhubungan dengan pendidikan dan pengajaran agama (Gani,1955: 18).

Di masa Orde Baru, Kementerian Agama diubah namanya menjadi Departemen Agama. Berdasarkan Kepres No. 15 Tahun 1984 Tentang Susunan Departemen, dinyatakan bahwa Departemen Agama merupakan bagian integral dari Pemerintahan Negara Indonesia, yang dipimpin oleh seorang menteri yang bertanggung jawab langsung kepada Presiden. Tugas pokok departemen ini menyelenggarakan sebagian dari tugas umum pemerintah dan pembangunan di bidang agama, termasuk pembangunan pendidikan agama (Departemen Agama RI, 1996: 17). Selama Orde Baru, beberapa pejabat telah ditunjuk sebagai Menteri Agama, mulai dari K.H. Moh. Dahlan (1967-1971), Prof. Dr. H.A. Mukti Ali (1971-1978), H. Alamsjah Ratu Prawiranegara (1978-1983), H. Munawir Sjadzali, M.A. (1983-1993) dan Dr. H. Tarmizi Taher (1993-1998). Oleh karena Departemen Agama RI merupakan bagian integral dari pemerintah Orde Baru, maka segala tugas, fungsi dan perannya senantiasa diarahkan pada program pembangunan Orde Baru yang bertumpu pada tiga hal, yaitu stabilitas politik, pertumbuhan ekonomi dan pemerataan pembangunan. Dengan bertumpu pada tiga hal tersebut, maka Departemen Agama selaku pemangku tugas pembangunan bidang agama, telah menetapkan 'Tiga Prioritas Nasional Kehidupan Beragama', yaitu:

1. Memantapkan ideologi dan falsafah Pancasila dalam kehidupan umat beragama dan di dalam lingkungan aparatur Departemen Agama.

2. Membantu usaha memantapkan stabilitas dan ketahanan nasional dengan membina Tiga Kerukunan Hidup Beragama (kerukunan intern umat beragama, kerukunan antar umat beragama dan kerukunan antar umat beragama dan pemerintah). 
3. Meningkatkan partisipasi umat beragama dalam menyukseskan dan mengamalkan pelaksanaan pembangunan nasional di segala bidang yang berkelanjutan.

(Departemen Agama RI, 1980: 9-10).

Dengan Tiga Prioritas Nasional di atas, tujuan pembangunan agama diarahkan untuk menciptakan empat kondisi, yaitu 1) masyarakat Pancasila yang agamis dan masyarakat agama yang Pancasilais; 2) seluruh umat beragama menjadi unsur utama dari Negara yang berdasarkan Pancasila; 3) masyarakat beragama menempatkan diri sebagai modal utama pembangunan, keamanan dan ketahanan nasional dari Negara yang berdasarkan Pancasila; dan 4) Agama menjiwai kehidupan bangsa Indonesia dan mempengaruhi sikap hidup, tingkah laku dan perbuatan sehari-hari (Departemen Agama RI, 1980: 6). Dengan demikian, pembangunan dan pembinaan pendidikan agama merupakan bagian integral dari eksistensi Departemen Agama.

Secara struktural-birokratis tugas pembinaan dan pengelolaan pendidikan agama oleh Departeman Agama dibagi ke dalam dua kategori, yaitu pendidikan agama untuk tingkat dasar dan menengah dan pendidikan agama untuk tingkat tinggi. Di awal Orde Baru (1967-1980), pengelolaan pendidikan agama tingkat dasar dan menengah berada di bawah naungan Direktorat Pendidikan Agama, yang strukturnya berada di bawah Direktorat Jenderal Bimbingan Masyarakat Islam (Rahim, 2001: 79-92).

Keluarnya Kepres No. 44 dan 45 Tahun 1975 tentang struktur organisasi departemen dan tata kerjanya, membuat direktorat pendidikan agama berubah menjadi direktorat pendidikan agama Islam yang tetap berada di bawah dan strukur Direktorat Jenderal Bimbingan Masyarakat Islam (Ditjen. Bimas. Islam). Direktorat ini membawahi empat subdit, yaitu subdit (sub dirtektorat) I Pengajaran, subdit II Pembinaan Penyelenggaraan Pendidikan, Subdit III Bina Sarana dan Subdit IV Pengamanan Teknis Pendidikan Agama Islam. Masingmasing subdit ini terdiri atas empat seksi yang sama, yaitu Seksi Sekolah Umum, Seksi Sekolah dan Perguruan Agama, Seksi Pondok Pesantren dan Seksi Pendidikan Guru dan Tenaga Ahli Agama.

Pada akhir Orde Baru (1980-1998), perkembangan pengelolaan pendidikan agama oleh Departemen Agama rupanya menunjukkan bahwa ia tidak cukup dikelola oleh satu direktorat. Oleh karena itu, berdasarkan Kepres No. 30 Tahun 1978 yang kemudian dijabarkan oleh KMA No. 6 Tahun 1979, pengelolaan pendidikan agama tidak lagi berada dalam lingkungan Ditjen Bimas Islam, tapi berada dalam direktorat jenderal tersendiri yang disebut Direktorat Jenderal Pembinaan Kelembagaan Agama Islam (Ditjen Binbaga Islam). Ditjen yang baru ini membawahi empat direktorat dan dua di antaranya merupakan pengembangan dari Direktorat Pendidikan Islam era sebelumnya. Kedua direktorat yang membawahi pendidikan agama ini adalah Direktorat Pembinaan Pendidikan Agama Islam pada Sekolah Umum (Ditbinpaisum) yang mengelola pelaksanaan pendidikan agama di sekolah-sekolah umum dan Direktorat 
Pembinaan Perguruan Agama Islam (Ditbinrua Islam) yang mengelola pelaksanaan pendidikan agama di sekolah-sekolah Islam, seperti madrasah, pondok pesantren dan madrasah diniyah (KMA No. 6 Tahun 1979).

Mengenai pendidikan agama tingkat tinggi, Departemen Agama awal Orde Baru mengeluarkan KMA No. 56 Tahun 1967 yang menyebutkan bahwa pelaksanaan pendidikan agama tingkat tinggi berada di bawah kewenangan Direktorat Perguruan Tinggi Agama dan Pesantren Luhur, yang secara struktural berada dalam lingkungan Ditjen Bimas Islam. Pada tahun 1969, direktorat ini berubah nama menjadi Direktorat Perguruan Tinggi Agama. Hingga akhir 1980, direktorat ini berubah lagi menjadi Direktorat Perguruan Tinggi Agama Islam. Kemudian di akhir Orde Baru, direktorat ini berubah lagi menjadi Direktorat Pembinaan Perguruan Tinggi Agama Islam (Ditbinperta Islam) (KMA No. 56 Tahun 1967).

Di era reformasi, pelaksanaan pendidikan agama oleh Departemen Agama RI dikelola oleh Direktorat Jenderal Pendidikan Islam. Ditjen ini membawahi empat direktorat, yaitu Direktorat Madrasah, Direktorat Pendidikan Diniyah dan Pondok Pesantren, Direktorat Pendidikan Agama Islam pada Sekolah dan Direktorat Pendidikan Tinggi Islam. Kemudian sejak 28 Januari 2010, menindaklanjuti Perpres No. 47 Tahun 2009 tentang Pembentukan dan Organisasi Kementerian Negara, Departemen Agama pun berubah kembali namanya menjadi Kementerian Agama (PMA No. 1 Tahun 2010).

Menurut Abdullah (1996: 96-97), Departemen Agama RI, secara birokratis senantiasa menjadi kaki tangan pemerintah untuk menyemaikan berbagai program pembangunan pemerintah, terutama dalam bidang pembinaan agama. Bahkan, dengan perannya, semua ormas (organisasi massa/masyarakat) agama di Indonesia dapat menerima Pancasila sebagai asas tunggal, sebagaimana diamanatkan dalam UU No. 3 Tahun 1985 tentang Parpol dan Ormas. Ini berkat jerih payah dan usaha tanpa kenal lelah, khususnya dari jajaran Departemen Agama. Ini merupakan prestasi besar dari Departemen Agama RI, sehingga setelah itu berakhirlah sejumlah kegaduhan yang mempersoalkan Pancasila. Prestasi ini sejalan dengan tugas Departemen Agama di masa Orde Baru memang diarahkan untuk ikut andil dalam mewujudkan masyarakat Pancasila yang agamis dan masyarakat agama yang Pancasilais. Oleh karena itu semua energinya ditujukan pada upaya penerimaan masyarakat terhadap asas tunggal Pancasila (Prawiranegara, 1996: 95).

\section{Dilema Madrasah}

Pendidikan swasta dalam arti pendidikan yang tidak diselenggarakan oleh pemerintah secara praktis telah ada sepanjang sejarah pendidikan di Indonesia. Asal-mula dan alasan diselenggarakannya pendidikan swasta bermacam-macam. Satu hal yang jelas, bahwa motif diadakannya pendidikan swasta, karena pemerintah tidak selalu dapat memenuhi segala kebutuhan dari semua golongan dalam masyarakat. Pada masa pemerintahan Hindia Belanda misalnya, dengan 
sendirinya orang atau kelompok yang menginginkan pendidikan agama bagi anak-anaknya mengadakan usaha khusus, yaitu mendirikan sekolah di mana unsur agama mendapat tempatnya sesuai dengan yang diinginkan oleh masyarakat. Agama itu diberikan bukan hanya sebagai mata pelajaran, tetapi seluruh pengajaran itu diresapi oleh suasana dan jiwa keagamaan, sehingga usaha mereka merupakan suatu usaha "pendidikan" dalam arti yang sebenarnya, yaitu anak-anak dibentuk menjadi manusia yang berkepribadian sesuai dengan kepercayaan dan keyakinannya (Poerbakawatja, 1970: 206).

Pada masa sebelum Orde Baru, pendidikan atau sekolah yang diselenggarakan bukan oleh pemerintah disebut dengan "sekolah partikelir". Sekolah partikelir merupakan perkembangan lanjutan dari sekolah yang telah ada pada masa pemerintahan Hindia Belanda yang disebut dengan "Sekolah Liar", yaitu sekolah yang didirikan oleh orang-orang Indonesia untuk anak-anak bumi putra/Indonesia (Suminto, 1996: 47 dan 59).

Pada masa itu, sekolah partikelir dihadapkan pada dua permasalahan, yaitu 1) adanya keinginan untuk 'menyamakan' sekolah partikelir dengan sekolah pemerintah; dan 2) adanya keinginan untuk tidak mengarahkan sekolah partikelir 'disamakan' dengan sekolah pemerintah. Berarti, sekolah partikelir harus mempunyai sikap dan ciri khas tersendiri. Dengan dasar demokrasi, sekolah partikelir sesungguhnya merupakan inisiatif yang mempunyai kedudukan penting dalam kehidupan masyarakat, karena memiliki sifat khas yang berbeda dengan pemerintah. Apabila sekolah partikelir dipaksakan untuk disamakan dengan sekolah pemerintah, maka sifat inisiatif yang dimilikinya akan luntur, karena "mengekor" kepada pemerintah. Dampak "mengekor" ini adalah munculnya sekolah partikelir yang tidak dapat memperkokoh kedudukan negara, bahkan dapat mempercepat runtuhnya mutu pendidikan negara. Dampak lain dari "mengekor" ini adalah terwujudnya sistem pendidikan tunggal yang justru berbahaya. Pendidikan/sekolah partikelir menjadi kaku dan tidak mudah menerima perubahan, karena terikat oleh sistem pendidikan tunggal pemerintah jajahan (Djambek, 1956: 6-7).

Pasca kemerdekaan, pemerintah RI menerapkan UU No. 12 Tahun 1954 yang di antaranya mengatur sekolah partikelir. Menurut pasal 13 UU ini, atas dasar kebebasan tiap-tiap warga untuk menganut suatu agama atau keyakinan hidupnya, maka kesempatan yang leluasa diberikan pula kepadanya untuk mendirikan dan menyelenggarakan sekolah-sekolah partikelir. Pasal 14 UU ini kemudian menyatakan bahwa sekolah-sekolah partikelir yang memenuhi syarat, dapat menerima subsidi dari pemerintah untuk pembiayaannya. Atas dasar dan titik tolak demokrasi, sekolah-sekolah partikelir banyak bermunculan di masa Indonesia merdeka. Untuk ini pemerintah bersedia memberi sokongan, terutama pendanaan. Dalam konteks Indonesia sebelum masa Orde Baru, kemunculan sekolah-sekolah swasta/partikelir dilandasi oleh adanya alam dan tuntutan demokrasi yang memberikan ruang dan kesempatan kepada masyarakat untuk 
menyelenggarakan pendidikan sesuai dengan kebutuhannya (Poerbakawatja, 1970: 208).

Kondisi di atas menjadi berbeda ketika Indonesia memasuki masa Orde Baru. Hingga tahun 1997, jumlah madrasah negeri dengan madrasah swasta tidak seimbang. Jumlah madrasah negeri, baik MI, MTs, maupun MA adalah 1.935 buah, sementara jumlah madrasah swasta baik MI, MTs maupun MA adalah 133.873 buah. Banyaknya madrasah swasta di masa Orde Baru ini sudah dipastikan bukan karena semangat demokrasi yang menghargai kebebebasan dan kemerdekaan para warganya untuk mendirikan madrasah-madrasah swasta di berbagai tempat di Indonesia. Madrasah-madrasah ini muncul karena motivasi keagamaan masyarakat yang begitu besar untuk mewakafkan dan membangun madrasah (Fadjar, 1999: 77).

Orde Baru dalam penilaian banyak ahli adalah rezim dengan karakter "birokratik otoritarian", yang dicirikan dengan adanya sikap apatis masyarakat terhadap proyek pembangunan pemerintah. Ciri lain watak birokratik otoritarian Orde Baru yaitu; 1) kekuasan tertinggi di tangan elit militer yang menggunakan pendekatan birokratik dan teknokratik dalam menjalankan kekuasaannya; 2) adanya ideologi konsensus untuk membungkam lawan-lawan politiknya; dan 3) adanya jaringan korporatis antara militer, birokrasi dan Golkar ('Partai' Golongan Karya) untuk mengontrol para oposisinya (Rohman, 2009: 177-178).

Dengan alasan demi stabilitas nasional dan stabilitas politik, Orde Baru senantiasa berperan sebagai faktor dominan ketika berhadapan dengan masyarakat. Begitu besar dominasi ini sehingga masyarakat berada dalam genggamannya. Dengan watak dan karakter rezim Orde Baru seperti ini, otomatis alam demokrasi tidak pernah terwujud. Oleh karena itu, besarnya jumlah madrasah pada masa Orde Baru seperti disebutkan di atas bukan karena alasan demokrasi, tapi lebih merupakan kehendak masyarakat yang dengan dasar motivasi keagamaan berlomba-lomba untuk mendirikannya.

Untuk kali pertama setelah terbit surat keputusan bersama (SKB) tiga menteri pada tahun 1975, pemerintah melalui Departemen Agama mengeluarkan peraturan yang berhubungan dengan penyelenggaraan madrasah swasta, yaitu Keputusan Menteri Agama No. 5 Tahun 1977 Tentang Persamaan Ijazah Madrasah Swasta dengan Ijazah Madrasah Negeri. Dalam keputusan tersebut disebutkan bahwa yang dimaksud dengan madrasah swasta adalah lembaga pendidikan yang diselenggarakan oleh organisasi, yayasan, badan atau perorangan sebagai pengurus/pemiliknya yang menjadikan mata pelajaran agama Islam sebagai mata pelajaran dasar yang diberikan sekurang-kurangnya 30\% di samping mata pelajaran umum. Madrasah swasta baik MI, MTs, maupun MA dapat memiliki status terdaftar atau disamakan. Madrasah dengan status terdaftar di Departemen Agama, para siswanya diperbolehkan mengikuti ujian madrasah negeri, sedangkan madrasah dengan status disamakan berdasarkan izin dari Direktorat Jenderal Bimbingan Masyarakat Islam dapat mengeluarkan ijazah sendiri yang nilainya sama dengan ijazah madrasah negeri yang setingkat. 
Madrasah swasta, baik terdaftar maupun disamakan, wajib membuat laporan periodik satu semester sekali kepada dirjen, hal tersebut sebagai sebuah bentuk bimbingan dan pengawasan (Dharma Bhakti, 1980).

Dua tahun kemudian, dalam rangka menindaklanjuti keputusan di atas, Menteri Agama mengeluarkan Peraturan Menteri Agama No. 3 Tahun 1979 Tentang Pemberian Bantuan Kepada Perguruan Agama Islam. Di dalam peraturan ini disebutkan bahwa yang dimaksud perguruan agama Islam yang berhak mendapat bantuan adalah lembaga perguruan agama Islam swasta, baik raudlatul athfal (RA), madrasah, madrasah diniyah (MD) maupun pondok pesantren yang diselenggarakan oleh organisasi, yayasan, badan atau perorangan sebagai pengurus/pemiliknya yang menjadikan mata pelajaran agama Islam sebagai mata pelajaran dasar pendidikannya. Khusus untuk madrasah, baik yang terdaftar maupun yang disamakan, mendapat bantuan pemerintah berupa sumbangan, tunjangan atau subsidi, apabila telah mendapat piagam status dari Departemen Agama dan mempergunakan kurikulum yang ditetapkan Departemen Agama. Dengan mendapat bantuan dari pemerintah, madrasah ini dianggap telah menyetujui sepenuhnya untuk menerima bimbingan dan pengawasan dari Dirjen Bimas Islam (Dharma Bhakti, 1980).

Sepuluh tahun kemudian, yaitu ketika UUSPN (Undang-Undang tentang Sistem Pendidikan Nasional) telah diberlakukan, pemerintah melalui Departemen Agama mencabut kedua peraturan di atas. Sebagai gantinya, dikeluarkan Keputusan Menteri Agama No. 310 Tahun 1989 Tentang Status Madrasah Swasta Di Lingkungan Direktorat Jenderal Pembinaan Kelembagaan Agama Islam. Dalam keputusan tersebut disebutkan bahwa madrasah swasta adalah madrasah yang didirikan oleh badan/perorangan yang bersifat sosial dengan tugas melaksanakan pendidikan berdasarkan sistem pendidikan nasional, dengan kurikulum yang ditetapkan Menteri Agama. Madrasah swasta yang baru didirikan mendapat status tercatat, yang kemudian dapat diakreditasi untuk penetapan statusnya, apakah terdaftar, diakui atau disamakan. Untuk melaksanakan KMA (Keputusan Menteri Agama) ini, Dirjen Binbaga Islam mengeluarkan dua keputusan, yaitu Keputusan Direktur Jenderal Pembinaan Kelembagaan Agama Islam No. 28A/E/1990 Tentang Syarat-Syarat dan Tata Cara Pendirian Madrasah Swasta dan Keputusan Direktur Jenderal Pembinaan Kelembagaan Agama Islam No. 29/E/1990 Tentang Pedoman Akreditasi Madrasah Swasta. Menurut kedua keputusan Dirjen ini, syarat pendirian madrasah swasta adalah: (1) diselenggarakan oleh penyelenggara madrasah yang bersifat sosial dan tidak mencari keuntungan; (2) mempunyai program pendidikan yang jelas; (3) melaksanakan kurikulum yang ditetapkan atau disahkan oleh Departemen Agama; (4) pada saat pembukaan, madrasah swasta memiliki kepala madrasah dan tenaga pengajar tetap; (5) tersedia murid yang memenuhi syarat sekurang-kuranynya 10 orang; dan (6) tersedia gedung/ruang belajar dan tidak menempati serta menggunakan fasilitas madrasah/sekolah milik pemerintah (Direktorat Pembinaan Badan Peradilan Agama Islam, 1995/1996). 
Madrasah swasta yang didirikan sesuai syarat-syarat di atas diberikan Nomor Statistik Madrasah (NSM) dalam bentuk piagam dengan status sebagai madrasah tercatat. Apabila madrasah swasta telah memiliki NSM, maka madrasah ini dapat dilakukan akreditasi, yaitu penilaian mutu madrasah swasta oleh Departemen Agama dengan tujuan untuk mendorong dan meningkatkan mutu pendidikan madrasah, mendorong terciptanya ketahanan madrasah dan lingkungannya, mendapatkan bahan-bahan bagi pembinaan madrasah bersangkutan, melindungi masyarakat dari usaha pendidikan yang tidak bertanggung jawab, memberikan informasi kepada masyarakat tentang mutu pendidikan madrasah dan untuk memudahkan pengaturan mutasi murid/siswa. Akreditasi tersebut dilakukan terhadap tujuh komponen, yaitu kelembagaan, kurikulum, administrasi, ketenagaan, murid/siswa, sarana/prasarana dan situasi umum madrasah. Dengan tujuh komponen ini, madrasah swasta dapat ditentukan statusnya, apakah terdaftar (kurang), diakui (cukup) atau disamakan (baik). Madrasah swasta yang telah ada diwajibkan untuk memperoleh piagam yang selanjutnya dilakukan proses akreditasi (Direktorat Pembinaan Badan Peradilan Agama Islam, 1995/1996).

Menjelang akhir kekuasaan Orde Baru, Menteri Agama memperbarui apa yang menjadi keputusannya pada 1989, dengan mengeluarkan Keputusan Menteri Agama No. 742 Tahun 1997 Tentang Status Madrasah Swasta Jenjang Pendidikan Dasar dan Menengah di Lingkungan Direktorat Jenderal Pembinaan Kelembagaan Agama Islam. Dari segi substansi, KMA 1997 ini sebenarnya materi hukumnya sama dengan KMA 1989. Hanya ada dua poin yang membedakannya, yaitu menyangkut pengertian madrasah swasta yang dalam KMA baru ini ditambahi kata "berciri khas agama Islam" dan menyangkut madrasah swasta yang baru berdiri, yang dalam KMA baru langsung mendapat status terdaftar, bukan lagi tercatat. Demikian pula untuk melaksanakan KMA ini Dirjen Binbaga Islam mengeluarkan dua keputusan, yaitu Keputusan Direktur Jenderal Pembinaan Kelembagaan Agama Islam No. E/250.A/1997 Tentang Syarat-Syarat dan Tata Cara Pendirian Madrasah Swasta Jenjang Pendidikan Dasar dan Menengah dan Keputusan Direktur Jenderal Pembinaan Kelembagaan Agama Islam No. E/25.A/1997 Tentang Pedoman Akreditasi Madrasah Swasta Jenjang Pendidikan Dasar dan Menengah. Kedua keputusan Dirjen 1997 ini pada intinya sama dengan kedua keputusan Dirjen 1990, yang membedakan adalah adanya status terdaftar, bukan tercatat, bagi madrasah swasta yang baru berdiri (Keputusan Menteri Agama No. 742 Tahun 1997 dan Keputusan Direktur Jenderal Pembinaan Kelembagaan Agama Islam No. E/250.A/1997).

Dari rangkaian kebijakan di atas, pola kebijakan akreditasi madrasah yang diterapkan secara sentralistik terhadap lembaga (madrasah) swasta dapat bermakna ganda; 1) jika diterapkan secara konsekuen dan dilandasi oleh asas pemberdayaan masyarakat (civil society) maka kebijakan akreditasi dapat menaikkan mutu madrasah. Kenyataannya perlakuan pemerintah terhadap 
madrasah terutama yang berstatus swasta tidak sama dengan perlakuan pemerintah terhadap sekolah. Di era Soeharto banyak didirikan SD Inpres (Sekolah Dasar Instruksi Presiden) dan statusnya negeri bahkan tidak berasal/mengembangkan dari sekolah (SD swasta) yang sudah ada. Artinya, SD Inpres diciptakan dari ketiadaan sejarah. Sebaliknya, pemerintah tidak pernah memogramkan pendirian MI Inpres. Padahal telah banyak MI swasta didirikan oleh masyarakat. Jika pemerintah Soeharto saat itu memiliki kemauan yang kuat memajukan dan memberdayakan masyarakat, mestinya pemerintah menggarap dan membangun terlebih dahulu madrasah yang sebelumnya sudah dirintis oleh masyarakat dalam bentuk madrasah swasta; 2) rezim Orde Baru yang menganut pembangunanisme yang memerlukan stabilitas politik dan pertumbuhan ekonomi dalam angka-angka. Untuk dapat mencapai stabilitas dan pertumbuhan ini, maka semua lembaga pemerintahan, termasuk di dalamnya birokrasi dan aparat pendidikan, harus memiliki posisi yang kuat dalam rangka mengontrol setiap perkembangan dan perilaku lembaga pendidikan swasta yang dibangun oleh masyarakat. Dalam konteks pendidikan alat tersebut adalah akreditasi. Ketika akreditasi itu diterapkan secara terpusat (sentralistik) maka akreditasi terhadap madrasah swasta sebetulnya dijalankan dalam rangka mengawasi dan mengontrol madrasah agar tidak mengganggu stabilitas politik dan pertumbuhan ekonomi. Jika ada indikasi (lulusan) madrasah swasta itu terlalu kritis terhadap pemerintah maka akreditasi dan sejumlah pemerintah tersebut dicabut kemudian ia diberi cap sebagai subversif. Saat masyarakat mengetahui bahwa banyak madrasah dianggap telah melakukan subversif maka madrasah menjadi termarjinalkan.

Kebijakan pendidikan di era Soeharto yang cenderung sentralistik berakibat pada lahirnya kebijakan pendidikan Islam yang juga sentralistik. Melalui Departemen Agama waktu itu, dibuatlah kebijakan akreditasi madrasah, yang secara kualitas sulit dicapai oleh madrasah swasta sebab sejak awal tidak pernah diprogram untuk meraih akreditasi/kualitas itu. Madrasah negeri pun pada dasarnya sama. Mereka diwajibkan untuk memperoleh piagam dan berarti harus mengambil sejumlah konsekuensi dari kenegerian atau pengakreditasiannya yaitu harus menyetujui sepenuhnya segala bentuk bimbingan dan pengawasan Direktorat Jenderal Bimbingan Masyarakat Islam yang sudah diformat oleh rezim Soeharto. Secara kualitas, meskipun sudah dinegerikan dan diakreditasi, madrasah negeri tersebut tetap tidak bisa bersaing dengan sekolah umum karena ada sejumlah perlakuan yang berbeda antara madrasah dengan sekolah umum. Bagi mereka/lulusan madrasah yang hendak melanjutkan studi ke perguruan tinggi negeri/mengikuti Sipenmaru (Sistem Penerimaan Mahasiswa Baru) harus terlebih dahulu telah mengikuti ujian nasional (UAN/EBTANAS) persamaaan pada sekolah umum yang ditunjuk. Masyarakat akhirnya kurang memercayai madrasah sekalipun statusnya negeri. Madrasah kembali termarjinalkan oleh sistem sentralistik tersebut. 
Dalam konteks politik pendidikan, kebijakan pendidikan masa Orde Baru dilakukan semata-mata sebagai sebuah bentuk hegemoni dan dominasi agar terbentuk suatu konsensus atas ide dan kultur dalam penyelenggaraan pendidikan. Gramsci mengatakan bahwa persemaian ide dan kultur kelompok berkuasa merupakan suatu keharusan agar tercipta hegemoni dan kekuasaannya mendapat legitimasi massa. Kelompok berkuasa sedemikian rupa berupaya membuat kelompok subordinat (kaum muslim Indonesia) menerima ide-ide, prinsip-prinsip atau norma-norma yang dimiliki penguasa agar menjadi milik semuanya. Oleh karena itu merupakan hal yang wajar jika "pandangan dunia" model Orde Baru sedemikian rupa dijabarkan melalui berbagai kebijakan, termasuk kebijakan untuk mengatur pendidikan Islam. Harapannya madrasah, terutama yang berstatus swasta menerima ideologisnya. Sekali "pandangan dunia" kelompok berkuasa sudah diterima dan diinternalisasi oleh kelompok subordinat, maka kelompok berkuasa itu telah berhasil memantapkan dan melanggengkan kekuasaannya (Sugiono, 1999: 40).

\section{SIMPULAN}

Selama 32 tahun Soeharto (Orde Baru) berkuasa, telah banyak cara untuk melanggengkan kekuasaannya, salah satunya melalui sentralisasi madrasah dan diskriminasi madrasah sehingga ia selalu berada dalam keadaan dilematis. Kebijakan akreditasi terhadap madrasah swasta oleh Orde Baru, dilakukan agar semua madrasah dapat dikontrol dan diawasi keberadaannya secara sentralistik. Meskipun jumlah madrasah era Orde Baru meningkat cukup siginifkan, yaitu 90\%-nya berstatus swasta, namun madrasah-madrasah swasta ini muncul dan berkembang lebih didorong oleh inisiatif masyarakat Muslim Indonesia yang termotivasi oleh semangat keagamaan, bukan oleh birokrasi pendidikan Orde Baru yang sentralistik. Di sini Orde Baru sebagai rezim birokratik-otoritarian kiranya tidak dan belum berhasil mendorong lahirnya demokratisasi dalam dunia pendidikan. Kebijakan akreditasi terhadap madrasah swasta justru lebih dimaksudkan agar lembaga-lembaga swasta yang ada dapat "dibonsai" dan sedemikian rupa dapat mengikuti proses hegemoni yang dilakukannya baik secara koersif maupun persuasif. Dalih bahwa tujuan kebijakan akreditasi dilakukan untuk penilaian mutu madrasah swasta oleh Departemen Agama, hanya sebagai semboyan belaka. Secara politis, program akreditasi, ijazaisme dan persamaan pada zaman Orde Baru bertujuan menciptakan stabilitas politik, agar program melanggengkan kekuasaan mereka berjalan lancar. Jika melawan lakukan marjinalisasi.

\section{DAFTAR PUSTAKA}

Abbas, Hafid. 2003. "Menegakkan Dimensi HAM dalam Mereposisi Arah Penidikan Nasional" dalam Sjafnir Ronisef dkk. (eds.), Mengurai Benang Kusut Pendidikan: Gagasan Para Pakar Pendidikan. Cet. I; Yogyakarta: Pustaka Pelajar-Tranformasi UNJ. 
Abdullah, Taufik. 1996. "Dari Reputasi Lama ke Tantangan Mendatang", Makalah Tamu dalam 50 Tabun Departemen Agama: Perjuangan dan Pengabdian. Jakarta: Depag RI.

Azra, Azyumardi. 1998. "H.M. Rasjidi, M.A.: Pembentukan Kementerian Agama dalam Revolusi", dalam Azyumardi Azra dan Saiful Umam (eds.), MenteriMenteri Agama RI: Biografi Sosial-Politik. Cet. I; Jakarta: INIS-PPIM-Badan Libang Agama Depag RI.

Azra, Azyumardi. 1999. Esei-Esei Intelektual Muslim dan Pendidikan Islam. Cet. I; Jakarta: Logos.

Azra, Azyumardi. 2002. Paradigma Baru Pendidikan Nasional: Rekonstruksi dan Demokratisasi. Cet. I; Jakarta: Penerbit Buku Kompas.

Darmaningtyas. 2004. Pendidikan yang Memiskinkan. Cet. II; Yogyakarta: Galang Press.

Departemen Agama RI. 1980. Pola Kebijaksanaan Pemerintah di Bidang Agama dalam Pembangunan Nasional. Jakarta: Proyek Perencanaan Peraturan Perundangan Keagamaan.

Departemen Agama RI. 1996. Amal Bakti Departemen Agama RI: Eksistensi dan Derap Langkabnya. Edisi II; Jakarta: Depag RI.

Djambek, Sa'doedin. 1956. "Sekolah Partikulir”, Dunia Madrasah, No. 25 Tahun III, September.

Fadjar, A. Malik. 1998. Visi Pembaharuan Pendidikan Islam. Cet. I; Jakarta: LP3NI.

Fadjar, A. Malik. 1999. Madrasah dan Tantangan Modernitas. Cet. II; Bandung: Mizan-Yasmin.

Fakih, Mansour. 1996. Masyarakat Sipil untuk Transformasi Sosial: Pergolakan Ideologi LSM Indonesia, alih bahasa Muhammad Miftahudin. Cet. I; Yogyakarta: Pustaka Pelajar.

Gani,Usman. 1955. "Ichtisar Tugas Kementerian Agama dalam Lapangan Pendidikan”, Dunia Madrasah, No. 7 Tahun I, 5 Maret.

Ismail, Faisal. 1999. Ideologi Hegemoni dan Otoritas Agama: Wacana Ketegangan Kreatif Islam dan Pancasila. Cet. I; Yogyakarta: Tiara Wacana.

Keputusan Direktur Jenderal Pembinaan Kelembagaan Agama Islam No. 28A/E/1990 Tentang Syarat-Syarat dan Tata Cara Pendirian Madrasah Swasta, sebagaimana dimuat dalam Himpunan Peraturan Perundang-Undangan Sistem Pendidikan Nasional: Seri Perguruan Agama Islam. Jakarta: Direktorat Pembinaan Badan Peradilan Agama Islam, 1995/1996.

Keputusan Direktur Jenderal Pembinaan Kelembagaan Agama Islam No. 29/E/1990 Tentang Pedoman Akreditasi Madrasah Swasta, sebagaimana dimuat dalam Himpunan Peraturan Perundang-Undangan Sistem Pendidikan Nasional: Seri Perguruan Agama Islam. Jakarta: Direktorat Pembinaan Badan Peradilan Agama Islam, 1995/1996.

Keputusan Direktur Jenderal Pembinaan Kelembagaan Agama Islam No. E/250.A/1997 Tentang Syarat-Syarat dan Tata Cara Pendirian Madrasah Swasta Jenjang Pendidikan Dasar dan Menengah, sebagaimana dimuat 
dalam Himpunan Peraturan Perundang-Undangan Tentang Pendidikan Nasional (Perguruan Agama Islam). Jakarta: Dirjen Binbaga Islam Depag RI, $1999 / 2000$.

Keputusan Direktur Jenderal Pembinaan Kelembagaan Agama Islam No.

E/25.A/1997 Tentang Pedoman Akreditasi Madrasah Swasta Jenjang

Pendidikan Dasar dan Menengah, sebagaimana dimuat dalam Himpunan

Peraturan Perundang-Undangan Tentang Pendidikan Nasional (Perguruan Agama

Islam). Jakarta: Dirjen Binbaga Islam Depag RI, 1999/2000.

Keputusan Menteri Agama No. 310 Tahun 1989 Tentang Status Madrasah

Swasta Di Lingkungan Direktorat Jenderal Pembinaan Kelembagaan

Agama Islam, sebagaimana dimuat dalam Himpunan Peraturan Perundang-

Undangan Sistem Pendidikan Nasional: Seri Perguruan Agama Islam (Jakarta:

Direktorat Pembinaan Badan Peradilan Agama Islam, 1995/1996.

Keputusan Menteri Agama No. 5 Tahun 1977 Tentang Persamaan Ijazah

Madrasah Swasta dengan Ijazah Madrasah Negeri, sebagaimana dimuat

dalam Abdul Rachman Shaleh, Penyelenggaraan Madrasah: Peraturan Perundangan. Jakarta: Dharma Bhakti, 1980.

Keputusan Menteri Agama No. 742 Tahun 1997 Tentang Status Madrasah

Swasta Jenjang Pendidikan Dasar dan Menengah Di Lingkungan Direktorat Jenderal Pembinaan Kelembagaan Agama Islam, sebagaimana dimuat dalam Himpunan Peraturan Perundang-Undangan Tentang Pendidikan Nasional (Perguruan Agama Islam). Jakarta: Dirjen Binbaga Islam Depag RI, 1999/2000.

Koesnodiprodjo. (t.t.) Himpunan Undang-Undang, Peraturan-Peraturan, PenetapanPenetapan Pemerintah Republike Indonesia 1946. Cet. II; Jogjakarta: Kantor Urusan Pegawai Negeri.

Mastuhu. 2004. Menata Ulang Pemikiran Sistem Pendidikan Nasional dalam Abad Ke21. Cet. II; Yogyakarta: Safiria Insania Press-MSI UII.

Peraturan Menteri Agama No. 3 Tahun 1979 Tentang Pemberian Bantuan Kepada Perguruan Agama Islam, sebagaimana dimuat dalam Abdul Rachman Shaleh, Penyelenggaraan Madrasab: Peraturan Perundangan. Jakarta: Dharma Bhakti, 1980.

Peraturan Menteri Agama RI No. 1 Tahun 2010, tentang Perubahan Penyebutan Departemen Agama Menjadi Kementerian Agama.

Poerbakawatja, Soegarda. 1970. Pendidikan dalam Alam Indonesia Merdeka. Jakarta: Gunung Agung.

Prawiranegara, H. Alamsjah Ratu. 1996. "Peranan Departemen Agama RI dalam 50 Tahun Indonesia Merdeka", Makalah Tamu dalam 50 Tabun Departemen Agama: Perjuangan dan Pengabdian. Jakarta: Depag RI.

Rahim, Husni. 2001. Arah Baru Pendidikan Islam di Indonesia. Cet. I; Jakarta: Logos.

Rohman, Arif. 2009. Politik Ideologi Pendidikan. Cet. I; Yogyakarta: LaksBang Mediatama. 
Sugiono, Muhadi. 1999. Kritik Antonio Gramsci Terbadap Pembangunan Dunia Ketiga. Cet. I; Yogyakarta: Pustaka Pelajar.

Suminto, H. Aqib. 1996. Politik Islam Hindia Belanda. Cet. III; Jakarta: LP3ES.

Suparno, Paul. dkk. 2003. Reformasi Pendidikan: Sebuah Rekomendasi. Cet. II; Yogyakarta: Kanisius.

Suyanto dan Djihad Hisyam. 2000. Refleksi dan Reformasi Pendidikan di Indonesia Memasuki Milenium III. Cet. I; Yogyakarta: Adicita Karya Nusa.

Team Pembinaan Penatar dan Bahan Penataran Pegawai Republik Indonesia. 1978. Bahan Penataran Pedoman Penghayatan dan Pengamalan Pancasila, UndangUndang Dasar 1945 dan Garis-Garis Besar Haluan Negara. Jakarta: Sekretariat Team Pembinaan Penatar dan Bahan Penataran Pegawai Republik Indonesia.

Tilaar, H.A.R. 1998. Beberapa Agenda Reformasi Pendidikan Nasional dalam Perspektif Abad Ke-21. Cet. I; Magelang: Tera Indonesia.

Tilaar, H.A.R. 2002. Membenabi Pendidikan Nasional. Cet. I; Jakarta: Rineka Cipta.

Zamroni. (t.t.) Pendidikan Untuk Demokrasi: Tantangan Menuju Civil Society. Cet. I; Yogyakarta: Bigraf Publishing.

Zamroni. 2000. Paradigma Pendidikan Masa Depan. Cet. I; Yogyakarta: Bigraf Publishing. 